\section{Influence of tidal stress on the immunocompetence of hemocytes in soft-shell clam (Mya arenaria)}

\author{
A. Beaudry, ${ }^{1,2,3}$ \\ C. Brousseau-Fournier, ${ }^{1,2,3}$ G. Alix, ${ }^{1,2,3}$ \\ M. Fortier, ${ }^{2}$ M. Auffret, ${ }^{4}$ \\ P. Brousseau, 1,2,3 M. Fournier ${ }^{1,2,3}$ \\ ${ }^{1}$ Parc de la rivière Mitis, Ste-Flavie, \\ Quebec, Canada; 'INRS-Institut Armand- \\ Frappier, Laval, Quebec, Canada; \\ 3Université du Québec à Rimouski, \\ Rimouski, Quebec, Canada; ${ }^{4}$ Université \\ de Bretagne Occidentale, Brest, France
}

\section{Introduction}

By their large distribution in the intertidal zone and continuous exposure to different biotic and abiotic stress in water and sediments, molluscs, such as Mya arenaria, are good sentinel species of environment quality. ${ }^{1,2}$ To determine the impact of different stress, an evaluation of the alteration of the main immune function of hemocytes, phagocytosis, can be readily determine in these invertebrates. ${ }^{3}$ It has been shown that these stressors could impact on the effectiveness of the immune system in molluscs to fight against diseases. ${ }^{4}$

Indeed hemocytes, which are responsible for phagocytosis, are altered by various environmental factors such as salinity, temperature and $\mathrm{pH}$ modification, ${ }^{5-7}$ by pathogens, ${ }^{8-10}$ and pollution. ${ }^{5,10-14}$ Exposure to these multiple stresses affects the immune system of molluscs and could increase their susceptibility to develop infectious diseases and cancers. ${ }^{15}$ However, in terms of physical stress, the effect of tides in respect to the position of clams on the shore were rarely been taken into account in immunological research. The objective of the present study is to determine if the shore spatial distribution (upper, middle and lower shore), can also influence the phagocytic competence of soft-shell clams.

\section{Materials and Methods}

\section{Animals}

Clams were collected, at low tide at three different sites (Anse, Jardins, Motel) and at three altimetric distances from the shore (upper shore, middle shore and lower shore) in Mitis Bay $\left(48^{\circ} 40^{\prime} \mathrm{N}, 68^{\circ} 00^{\prime} \mathrm{W}\right)$. Upper shore
Mya arenaria were exposed to air for circa $5 \mathrm{~h}$, the middle shore for $2 \mathrm{~h}$ and the lower shore individuals were exposed for $30 \mathrm{~min}$.

\section{Determination of phagocytosis}

Hemolymph was extracted from the posterior adductor muscle using $3 \mathrm{~mL}$ syringe and 23 $G$ needle and transferred on ice in tubes. Phagocytosis was monitored according to the method developed by our laboratory. ${ }^{16}$ Hemocytes were mixed with yellow-green latex FluoSpheres (Molecular Probes Inc., Eugene, OR, USA) at a ratio of 1:100 (hemocytes:beads) in flat-bottom 96 wells plate. The mixtures were incubated at $20^{\circ} \mathrm{C}$ in the dark. After $18 \mathrm{~h}$, the supernatant was delicately removed by decantation. The cells were fixed with $0.5 \%$ formalin. Phagocytosis was measured by flow cytometry (FACScan, Becton Dickinson, San Jose, CA, USA). A total of 3000 events were acquired for each sample and stored in the list mode data format. The data were then analysed, once displayed as two-parameter complexity and cell size, in the process of gating the hemocytes population and as fluorescence (FL1) frequency distribution histogram for phagocytosis. The results of one bead and more represent the phagocytic activity and three beads and more represent the efficacy of phagocytosis. Data collection and analysis were performed with LYSIS-II program.

\section{Statistical treatments}

The effect of tides and shore locations were examined by ANOVA followed by Tukey's test for pairwise comparisons. Statistical analyses were performed using SigmaStat (version 3.5). Significance was set at $\mathrm{P}<0.05$.
Correspondence: Michel Fournier, Institut National de la Recherche Scientifique-InstitutArmand-Frappier (INRS-IAF) 531 boul. des Prairies, Laval, Quebec, Canada H7V 1B7.

E-mail: Michel.Fournier@iaf.inrs.ca

Key words: Mya arenaria, immunocompetence, hemocytes.

Conference presentation: part of this paper was presented at the ECOBIM meeting, 2013 May, Montréal, Quebec, Canada.

This work is licensed under a Creative Commons Attribution NonCommercial 3.0 License (CC BYNC 3.0).

(c) Copyright A. Beaudry et al., 2013

Licensee PAGEPress, Italy

Journal of Xenobiotics 2013; 3(s1):e13

doi:10.4081/xeno.2013.s1.e13

\section{Results}

The phagocytic activity and efficacy of phagocytosis for the site Jardins in Mitis Bay, for three altimetrics levels (top, middle and bottom range) are presented in Figure 1. Note that soft-shell clams located in top and middle ranges have phagocytic activity significantly lower than those from bottom site $(18.7 \%$ and $12.9 \%$ respectively). For the phagocytic efficacy, there is also a significant decrease in top and middle locations when compared to low location. Similar results were obtained for the other two sites.

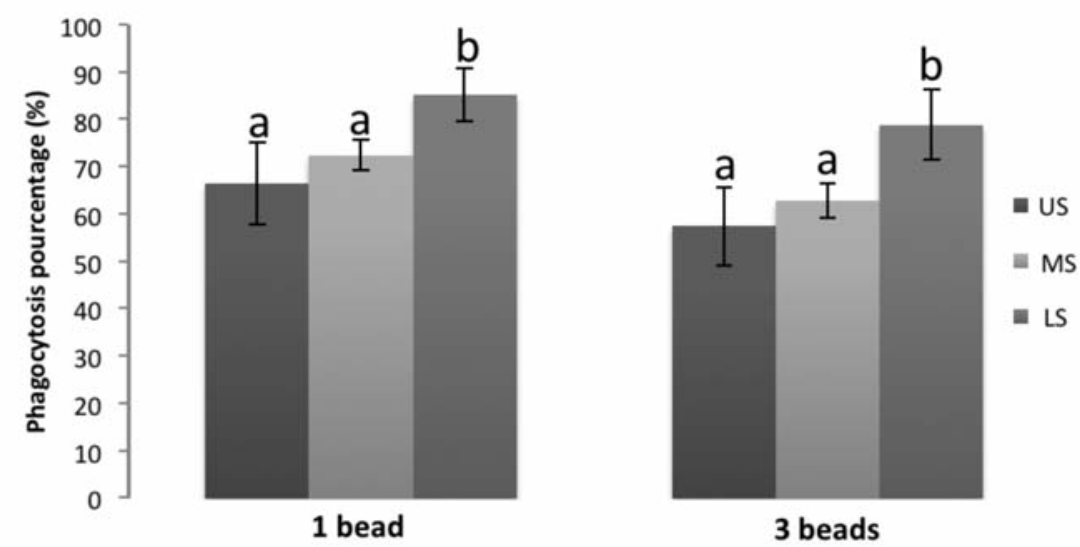

Figure 1. Phagocytosis activity ( 1 bead and more) and phagocytosis efficacy ( 3 beads and more) of Mya arenaria at upper shore (US), middle shore (MS) and lower shore (LS) from the site Jardins in Mitis Bay on July $31^{\text {st }} 2012(n=15)$. 


\section{Discussion}

The distribution of Mya arenaria in intertidal zone is highly variable and has an influence on several physiological characteristics of this species. The immersion time, varies with the altimetric position on the shore and has an effect on the allocation of resources in relation to the ingested energy by filtration and the reproductive cycles. ${ }^{17-21}$ Among all these physiological changes caused by the positioning in the intertidal area, we can now add the variation of immunocompetence as shown by our results, which tends to decrease with an extension of the period of desiccation. It was also shown that increasing the immersion time changes adaptive strategies ${ }^{17,22}$ to optimize the allocation of energy leading to altered growth of soft-shell clams. ${ }^{17,23}$ As preliminary results, in our experiment, we have also observed that clams collected lower shore, are at least one and a half fold bigger than those collected in upper shore. Based on our study, in future immunotoxicology studies, it would be important to include the natural variation of the phagocytic activity of soft-shell clams due to their position on the shore with a preference to do the sampling near the low water line to get the best witnesses.

\section{References}

1. Fournier M, Pellerin J, Clermont Y, Morin Y, Brousseau P. Effects of in vivo exposure of Mya arenaria to organic and inorganic mercury on phagocytic activity of hemocytes. Toxicology 2001;161:201-11.

2. Cooper Je, Knowler C. Investigations into causes of death of endangered molluscs (Partula species). Vet Rec 1992;131:342-4.

3. Fournier M, Cyr D, Blakley B, Boermans H, Brousseau P. Phagocytosis as a biomarker of immunotoxicity in wildlife species exposed to environmental xenobiotics. Am Zool 2000;40:412-20.

4. Malagoli D, Casarini L, Sacchi S, Ottaviani E. Stress and immune response in the mussel Mytilus galloprovincialis. Fish Shellfish Immun 2007;23:171-7.

5. Renwrantz L. Internal defence system of Mytilus edulis. In: Stefano GB, ed. Studies in neuroscience, neurobiology of Mytilus edulis. Manchester: Manchester University Press; 1990. pp 256-275.

6. Matozzo V, Marin MG. 2011. Bivalve immune responses and climate changes: is there a relationship? ISJ 2011;8:70-7.

7. Fisher WS. Environmental influence on bivalve haemocyte function. Am Fish Soc Spec Publ 1988;18:225-37.

8. Oliver LM, Fisher WS. Appraisal of prospective bivalve immunomarkers. Biomarkers 1999;4:510-30.

9. Oubella R, Maes P, Paillard C, Auffret M. Experimentally induced variation in hemocyte density for Ruditapes philippinarum and R. decussatus (Mollusca, Bivalvia). Dis Aquat Org 1993;15:193-7.

10. Anderson DP, Paynter KT, Burreson EM. Increased reactive oxygen intermediate production by hemocytes withdraw from Crassostrea virginica infected with Perkinsus marinus. Biol Bull 1992;183: 476-81.

11. Sauvé S, Brousseau P, Pellerin J, Morin Y, Senécal L, Goudreau P, et al. Phagocytic activity of marine and freshwater bivalves: in vitro exposure of hemocytes to metals (Ag, Cd, Hg and $\mathrm{Zn}$ ). Aquat Tox 2002;58: 189-200.

12. Fisher WS, Oliver LM, Walker WW, Manning CS, Lytle TF. Decreased resistance of eastern oysters (Crassostrea irginica) to a protozoan pathogen (Perkinsus marinus) after sublethal exposure to tributyltin oxide. Mar Environ Res 1999;47:185-201.

13. Coles JA, Fairly SR, Pipe RK. The effects of fluoranthene on the immuno-copetence of the common marine mussel, Mytilus edulis. J Aquat Toxicol 1994;30:367-79.

14. Cheng TC. In vivo effects of heavy metals on cellular defense mechanisms of crassostrea irginica: phagocytic and endocytic indices. J Invertebr Pathol 1998;51:215-20.

15. Blaise C, Gagné F, Pellerin J, Hansen P-D, Trottier S. Molluscan shellfish biomarker study of the Quebec, Canada, Saguenay fjord with the softshell clam Mya arenaria. Environ Toxicol 2002;17:170-86.

16. Brousseau P, Pellerin J, Morin Y, Cyr D, Blakley B, Boermans H, et al. Flow cytometry as a tool to monitor the disturbance of phagocytosis in the clam Mya arenaria hemocytes following in vitro exposure to heavy metals. Toxicology 2000;142:145-56.

17. Roseberry L, Vincent B, Lemaire C. Croissance et reproduction de Mya arenaria dans la zone intertidale de I'estuaire du Saint-Laurent. Can J Zool 1991;69:72432.

18. Barbault R, Blandin P. La notion de stratégie adaptative: sur quelques aspects énergétiques, démographiques et synécologiques. In: Barbault R, Blandin P, Meyer JA, eds. Problèmes d'écologie théorique: les stratégies adaptatives. Paris: Maloine; 1980. pp 1-27.

19. Calow P. The evolution of life-cycle strategies in fresh water gastropods. Malacologia 1978;12:351-64.

20. Calow P. The relationship between fecondity, phenology and longevity: a system approach. Am Nat 1973;107:559-64.

21. Hubbell SP. 1971. Of sowbugs and systems: the ecological energetics of a terrestrial isopod. In: Patten BC, ed. Systems analysis and simulation in ecology. New York: Academic Press; 1971. pp 269-323.

22. Barbault R. Ecologie des populations et des peuplements: des théories aux faits. Paris: Masson; 1981.

23. Newell RC, Et Hidu H. The effects of sediment type on growth rate and shell allometry in the soft shelled clam Mya arenaria L. J Exp Mar Biol Ecol 1982;65:285-95. 